\title{
Scrapie susceptibility in meat sheep of Paraná State - Brazil
}

\section{Susceptibilidade ao scrapie em ovinos de corte do Estado do Paraná - Brasil}

\section{Cristina Santos Sotomaior ${ }^{[a]}$, Vanete Thomaz-Soccol ${ }^{[b]}$}

\begin{abstract}
The aim of this study is to investigate the scrapie susceptibility of the main breeds of meat sheep raised in the state of Paraná, Brazil. Three hundred and twenty-five animals of meat breeds (including Suffolk, Hampshire Down, Texel, lle de France, Dorper, Dorset, Santa Inês, and crossbreds) were genotyped by Restriction Fragment Length Polymorphism (RFLP) and DNA sequencing for the prion protein gene. Using a classification for resistance and susceptibility from the British National Scrapie Plan, the genotypes observed for each breed were analysed. Animals from the Santa Inês breed and crossbred animals showed the highest genotypic variability. All breeds evaluated showed the presence of genotypes considered susceptible to scrapie. More than $56 \%$ of the animals tested fit into types 3, 4 or 5, the most susceptible groups. There is little data on PRPN genotyping in Brazil. So it is necessary to expand the available data on these breeds to implement a scrapie control program.
\end{abstract}

Keywords: Selective breeding. Polymorphism. Prion Protein Gene.

\section{Resumo}

Com o objetivo de discutir a susceptibilidade ao scrapie nas principais raças de corte criadas no Estado do Paraná, foram genotipados 325 animais das raças Suffolk, Hampshire Down, Texel, Ile de France, Dorper, Dorset, Santa Inês e mestiços. Duas técnicas foram utilizadas para a análise do polimorfismo do gene da proteína prion celular: PCR-RFLP (polimorfismo de comprimento de fragmentos de restrição) e sequenciamento gênico. A raça Santa Inês e os mestiços foram os que apresentaram a maior variabilidade genética. Usando a classificação britânica do National Scrapie Plan, foi possível analisar os genótipos de cada uma das raças estudadas. Em todas as raças, foram observados genótipos considerados susceptíveis ao scrapie, em diferentes porcentagens. Cinquenta e seis por cento dos animais genotipados estavam classificados nos tipos 3, 4 e 5, que são considerados os mais susceptíveis ao scrapie. Diferenças importantes foram observadas entre as raças. Mais dados brasileiros precisam ser disponibilizados antes que se possa implementar um programa de controle de scrapie em ovinos.

Palavras-chave: Cruzamento seletivo. Polimorfismo. Proteína Prion Celular. [a] Doutora e professora da Pontifícia Universidade Católica do Paraná (PUCPR), Centro de Ciências Agrárias e Ambientais, São José dos Pinhais, PR - Brasil.

${ }^{[b]}$ Doutora em Parasitologie Faculte de Medecine pelo Universite Montpellier I, França, professor sênior e orientador do núcleo permanente do Programa de Mestrado e de Doutorado em Processos Biotecnológicos (área de Saúde Humana e Animal) e Microbiologia, Parasitologia e Patologia da Universidade Federal do Paraná (UFPR), Curitiba, PR - Brasil, e-mail: cristina.sotomaior@pucpr.br; vasoccol@ufpr.br

Received: 08/12/2011

Recebido: 12/08/2011

Approved: 12/12/2011

Aprovado: 12/12/2011 


\section{Introduction}

Genetic susceptibility is a major determinant of scrapie, an infectious disease affecting sheep. Polymorphisms at codons 136 (alanine, A/valine, V), 154 (histidine, H/ arginine, R) and 171 (histidine, H/glutamine, Q/arginine, $\mathrm{R}$ ) of the prion protein gene (PRNP) seem to be associated with an increased risk of disease development for sheep exposed to the infectious agent of scrapie (1-5). The ARQ variant at codons 136,154 , and 171 is considered the ancestor allele, since the majority of prion protein (PrP) variants can be derived from a unique point mutation in the ARQ sequence. Among the possible combinations of amino acids in these three main codons, only five (ARR, ARQ ARH, AHQ VRQ) are normally found in sheep, and their homozygotic or heterozygotic pairs generate 15 possible genotypes $(1,5)$.

Various countries around the world have begun genotyping their flocks of sheep (6-16). In countries where scrapie is present, it is possible to study the association between genotypes and disease spread for different breeds. Controlled crossbreeding is also possible mainly in countries in which a scrapie control program already exists. In countries in which the disease is not reported, genotyping can be used to anticipate the degree of susceptibility of the flocks in case the agent becomes present. Accordingly, it is possible to determine the potential of proposed selection programs aimed at increasing disease resistance without losing or interfering with other reproductive characteristics.

Programs based on the selection of animals that are genetically resistant to scrapie have provided a new approach to control strategies. Such has been the strategy of choice in many countries, including Great Britain's adoption of the National Scrapie Plan (NSP) (http://www.defra.gov.uk). In general, these plans and programs are based on selection by crossbreeding, with varying degrees of selection pressure, and aim to increase the frequency of the ARR allele and diminish the VRQ frequency.

It is well-established that the ARR/ARR genotype susceptibility to the agents causing scrapie is extremely low, although no longer considered null (17). On the other hand, the VRQ allele is considered to be associated with high susceptibility $(3,6,10,11)$.

The combination of the remaining alleles present variable levels of susceptibility. Dawson et al. (5) proposed a classification for different allelic combinations, grouping the genotypes into five groups so that $\mathrm{R} 1$ is the most resistant and includes only the ARR/ARR genotype; R5 is the most susceptible and includes genotypes with allele VRQ with the exception of ARR/VRQ and AHQ/VRQ.

In Brazil, according to the World Organization for Animal Health (OIE), cases of scrapie were notified in 2000, 2001, 2003, 2005, and 2006 (http://www.oie.int). Out of these, only the 2005 cases did not occur in the state of Paraná. Nevertheless, the animals involved in this 2005 report were purebred Suffolk imported from Paraná. In addition, the 2003 cases were the first to be considered autochthonous in the country.

No control program for scrapie has been implemented in Brazil, and there is little data on PRPN genotyping. Thus, the aim of the present work is to analyze the genotyping results of meat breeds raised in the state of Paraná with regard to scrapie as outlined in the main scrapie control program in the world, Great Britain's NSP.

\section{Materials and methods}

\section{Flock Selection}

Samples were obtained from sheep representing the most common meat breeds of sheep raised in Paraná, including Suffolk, Hampshire Down, Texel, Ile de France, Dorper, Dorset, and Santa Inês. In addition, other breeds such as Crioula, Damara, and crossbred animals were also included. The samples were obtained from 56 flocks distributed across the state of Paraná.

\section{Genotype data}

PRNP was genotyped using Restriction Fragment Length Polymorphism (RFLP) according to Luhken et al. (12). Results from 28 samples were validated by DNA sequencing to confirm the genotypes generated by RFLP analysis.

\section{Classification as susceptible or resistant to scrapie}

The classification of samples as susceptible or resistant to scrapie followed the standards set forth in the National Scrapie Plan (http://www.defra.gov.uk), which was introduced for registered purebred flocks in Great Britain in 2001 and was extended to non-registered purebred flocks in 2002 (18). The program is based on a positive selection of breeders with allele 
ARR and the negative selection of the VRQ allele; the program, moreover, provides a table that summarizes restrictions on breeding according to the genotype of the animal (Table 1).

\section{Results}

A total of 325 samples from 56 flocks distributed across the state of Paraná were genotyped by PCR-RFLP and validated by DNA sequencing (Table 2). The allele and genotype frequencies have been published elsewhere (19).
Genotypes ARQ/ARQ and ARR/ARQ were found in all breeds, presenting variations only in terms of frequency. Genotype ARR/ARR was not observed in the Dorper and Santa Inês breeds. Genotype ARR/ AHQ was only observed in crossbred animals, and genotype ARQ/AHQ was observed in crossbred animals and in the Santa Inês breed. Genotypes with the VRQ allele were not observed in the Ile de France and Suffolk breeds. Among the analyzed breeds, those that presented the highest variability were the Santa Inês breed as well as the crossbreeds; each breed showed six different genotypes (Table 2).

Table 1 - Classification of different genotypes found in sheep with regard to the degree of susceptibility to scrapie, according to the NSP

\begin{tabular}{|c|c|c|}
\hline NSP Type & Genotype & Degree of resistance/susceptibility \\
\hline 1 & ARR/ARR & Sheep that are genetically most resistant to scrapie. \\
\hline 2 & $\begin{array}{l}\text { ARR/AHQ } \\
\text { ARR/ARH } \\
\text { ARR/ARQ }\end{array}$ & $\begin{array}{l}\text { Sheep that are genetically resistant to scrapie, but will need careful selection when used for } \\
\text { further breeding. }\end{array}$ \\
\hline 3 & $\begin{array}{l}\text { AHQ/AHQ } \\
\text { AHQ/ARH } \\
\text { AHQ/ARQ } \\
\text { ARH/ARH } \\
\text { ARH/ARQ } \\
\text { ARQ/ARQ }\end{array}$ & $\begin{array}{l}\text { Sheep that genetically have little resistance to scrapie and will need careful selection when used } \\
\text { for further breeding. }\end{array}$ \\
\hline 4 & ARR/VRQ & $\begin{array}{l}\text { Sheep that are genetically susceptible to scrapie and should not be used for breeding unless in } \\
\text { the context of an approved and controlled breeding programme. }\end{array}$ \\
\hline 5 & $\begin{array}{l}\text { AHQ/VRQ } \\
\text { ARH/VRQ } \\
\text { ARQ/VRQ } \\
\text { VRQ/VRQ }\end{array}$ & Sheep that are highly susceptible to scrapie and should not be used for breeding. \\
\hline
\end{tabular}

Source: Adapted from the NSP Genotypes Table. (http://www.defra.gov.uk/animalhealth/managing-disease/NSPAC/tables/genotypes.pdf)

Table 2 - Distribution (n) of genotypes according to breed of 325 animals genotyped using the PCR-RFLP method

\begin{tabular}{llllllllll}
\hline Breed & $\begin{array}{l}\text { Animals } \\
(\mathrm{n})\end{array}$ & $\begin{array}{l}\text { Flocks } \\
(\mathrm{n})\end{array}$ & $\begin{array}{l}\text { ARR/ } \\
\text { ARR }\end{array}$ & $\begin{array}{l}\text { ARR/ } \\
\text { ARQ }\end{array}$ & $\begin{array}{l}\text { ARQ/ } \\
\text { ARQ }\end{array}$ & $\begin{array}{l}\text { ARR/ } \\
\text { VRQ }\end{array}$ & $\begin{array}{l}\text { ARR/ } \\
\text { AHQ }\end{array}$ & $\begin{array}{l}\text { ARQ/ } \\
\text { VRQ }\end{array}$ & $\begin{array}{l}\text { ARQ/ } \\
\text { AHQ }\end{array}$ \\
\hline Crioula & 10 & 1 & 5 & 3 & 2 & - & - & - \\
Damara & 2 & 1 & - & - & 2 & - & - & - & - \\
Dorper & 27 & 7 & - & 3 & 17 & 1 & - & 6 & - \\
Dorset & 32 & 1 & 2 & 10 & 18 & - & - & 2 & - \\
Hampshire Down & 83 & 8 & 4 & 33 & 36 & 2 & - & 8 & - \\
Ile de France & 12 & 11 & 4 & 7 & 1 & - & - & - & - \\
Crossbreeds & 75 & 1 & 16 & 32 & 19 & 2 & - & 4 & 2 \\
Santa Inês & 28 & 7 & - & 8 & 12 & 2 & 1 & 3 & 2 \\
\hline
\end{tabular}


Table 2 - Distribution (n) of genotypes according to breed of 325 animals genotyped using the PCR-RFLP method

\begin{tabular}{llllllllll}
\hline Breed & $\begin{array}{l}\text { Animals } \\
(\mathbf{n})\end{array}$ & $\begin{array}{l}\text { Flocks } \\
(\mathrm{n})\end{array}$ & $\begin{array}{l}\text { ARR/ } \\
\text { ARR }\end{array}$ & $\begin{array}{l}\text { ARR/ } \\
\text { ARQ }\end{array}$ & $\begin{array}{l}\text { ARQ/ } \\
\text { ARQ }\end{array}$ & $\begin{array}{l}\text { ARR/ } \\
\text { VRQ }\end{array}$ & $\begin{array}{l}\text { ARR/ } \\
\text { AHQ }\end{array}$ & $\begin{array}{l}\text { ARQ/ } \\
\text { VRQ }\end{array}$ & $\begin{array}{l}\text { ARQ/ } \\
\text { AHQ }\end{array}$ \\
\hline Suffolk & 40 & 10 & 4 & 10 & 26 & - & - & - & - \\
Texel & 16 & 9 & 3 & 4 & 7 & - & - & 2 & - \\
\hline TOTAL & 325 & 56 & 38 & 110 & 140 & 7 & 1 & 25 & 4 \\
\hline
\end{tabular}

By classifying the animals according to the criteria of the British NSP (see Table 1), one observes that 14.4\% of the total number of genotyped animals fit type 1 , which do not require any restrictions for reproduction. Types 2 and 3 require careful selection when used for further breeding; of the animals classified in this study, $29.5 \%$ and $47.8 \%$ were type 2 and 3 , respectively. Types 4 and 5 are required to be thoroughly eliminated, either by castration or slaughtering, and we find that $1.6 \%$ and $6.7 \%$ of the genotyped animals fit these types, respectively. The classification of each breed according to the criteria of the NSP is seen in Table 3.

\section{Discussion}

No controlled breeding scheme for scrapie has been implemented in Brazil. Nevertheless, before a selective breeding program is proposed, it is essential to understand the population structure and the degree of variability of the PRNP across different breeds.
In the present work we have used the classification proposed by the National Scrapie Plan because of the worldwide importance of this control plan for scrapie. One must point out that the NSP has tested over 2 million sheep to date. With similar programs taking place within the European Union, this may be the largest genetic selection program ever put in place, and as such, it is generating a substantial amount of data on genotype frequencies across different sheep breeds from various countries and regions (20).

By assessing the percentage of resistant or susceptible genotypes in the various breeds, it is possible to predict the selection possibilities and difficulties within each breed if a selective breeding program is proposed.

When the genotyped animals presenting this study are classified, less than half of the animals (43.9\%) are classified into types 1 and 2 . For these two categories, there are no breeding restrictions for males, although type 1 (ARR/ARR) is more encouraged than type 2 . Very different results are observed with regard to individual breeds; some breeds are less than $15 \%$ for

Table 3 - Percentage of animals by breed according to their classification into Type 1, 2, 3, 4, or 5 according to the NSP classification

\begin{tabular}{|c|c|c|c|c|c|}
\hline \multirow{2}{*}{ Breed } & \multicolumn{5}{|c|}{$\%$ according to the Type by the NSP } \\
\hline & 1 & 2 & 3 & 4 & 5 \\
\hline Crioula & 50.0 & 30.0 & 20.0 & 0.0 & 0.0 \\
\hline Damara & 0.0 & 0.0 & 100.0 & 0.0 & 0.0 \\
\hline Dorper & 0.0 & 11.1 & 63.0 & 3.7 & 22.2 \\
\hline Dorset & 6.2 & 31.3 & 56.2 & 0.0 & 6.3 \\
\hline Hampshire Down & 4.8 & 39.8 & 43.4 & 2.4 & 9.6 \\
\hline Ile de France & 33.3 & 58.3 & 8.4 & 0.0 & 0.0 \\
\hline Santa Inês & 0.0 & 32.1 & 50.0 & 7.1 & 10.8 \\
\hline Suffolk & 10.0 & 25.0 & 65.0 & 0.0 & 0.0 \\
\hline Texel & 18.7 & 25.0 & 43.8 & 0.0 & 12.5 \\
\hline Crossbreeds & 21.3 & 42.7 & 28.0 & 2.7 & 5.3 \\
\hline TOTAL/average & 14.4 & 29.5 & 47.8 & 1.6 & 6.7 \\
\hline
\end{tabular}


types 1 and 2, such as the Dorper breed. Other breeds, such as the Ile de France, are 91.6\% for types 1 and 2 . Type 3, into which $47.8 \%$ genotypes were classified and in which almost all breeds have the largest number of representatives, is the most controversial category of all. There have been restrictions on the commercialization of sheep belonging to this group that are no longer applied, but there are still restrictions depending on the breed and on the type of raising. The type 4 genotypes constitute a special problem. Although these animals run a smaller risk of developing scrapie during their lives, they have the potential to generate type- 5 progeny, which has a great risk of disease if exposed to the scrapie agent. Thus, the restrictions on sheep in this group, as well as restrictions on type- 5 sheet, are severe, as these animals must be slaughtered or castrated. Among the animals genotyped for the present work, $8.3 \%$ would be classified into these two groups. More detailed evaluation of each breed is presented below.

\section{Suffolk}

Data observed on the Suffolk breed show the presence of only two alleles, ARR and ARQ. Suffolk is breed classified as having only these two alleles and, occasionally, the ARH allele (5). Overall, $65 \%$ of Suffolk sheep have the ARQ/ARQ alleles, 25\% have the ARR/ARQ alleles, and 10\% have the ARR/ARR alleles. This has raised a concern regarding the breed's susceptibility to scrapie, since in breeds like Suffolk, in which the VRQ allele is either rare or absent, the genotype $A R Q / A R Q$ is associated with a greater risk of scrapie (5). It has been suggested that the best way to control the disease in this breed would involve the elimination of all animals with QQ at codon 171, since they represent only $14 \%$ of animals without scrapie and $100 \%$ of those affected. In the data presented here, a control program based on the same elimination criterion would be impracticable, given that $65 \%$ of the animals are genotyped ARQ/ARQ (3). Moreover, there is also the possibility that ARR/ARQ animals are susceptible, although in a smaller proportion $(4,21)$.

In a review of NSP data (13), the genotypes of more than 36 thousand Suffolk sheep showed that the frequency of the ARR allele is much higher than that of the ARQ (75\% and 24\%, respectively). There was a very low frequency of ARH (1\%) and VRQ $(0.2 \%)$, confirming that this breed predominantly has ARR and ARQ alleles. These data, however, may take into account flocks in which guided breedings have already aimed to increase the ARR allele; this would in fact justify such high frequencies of these alleles.

According to other Brazilian data, the analysis of 129 Suffolk sheep for codons 136 and 171 presented $4 \%$ of AR/AR animals, $40 \%$ of AQ/AR animals, $49 \%$ of AQ/AQ animals, $6 \%$ of $\mathrm{AQ} / \mathrm{AH}$ animals, and $1 \%$ of AR/VQ animals (22).

The Suffolk breed has a historical importance in the state of Paraná. During the 80s, it was the breed raised most frequently by purebred sheep breeders. The import of these sheep occurred mainly from the United States, where scrapie is an endemic disease. If the Suffolk animals tested here were selected for breeding using the NSP classifications, only 35\% (types 1 and 2) would be bred.

\section{Hampshire Down (HD)}

In the present study, the VRQ allele is present in the HD breed, though in a low frequency $(0.6 \%)$. The $10 \%$ presence of ARQ/VRQ animals, which is one of the genotypes most susceptible to scrapie (only VRQ/ VRQ is considered more susceptible) raises concerns, because these are animals at risk if they contact the agents that cause scrapie. Additionally, the $43 \%$ presence of the genotype ARQ/ARQ, considered the most susceptible in valine breeds, together with the low percentage of ARR/ARR animals (only 5\%) further increase these concerns.

The Hampshire Down breed is also classified as one of the "alanine breeds" that only exhibit alleles ARR and ARQ and, occasionally, allele ARH (5). The presence of allele VRQ is rare. In the analysis of data on 2,158 NSP animals (13), it were registered the frequencies of alleles ARR and ARQ at $54.9 \%$ and $45 \%$, respectively. Alleles ARH, AHQ and VRQ were not found. Data from animals in the U.S. also show only alleles ARR and ARQ, and the most frequent genotype was ARR/ARQ (52.7\%), followed by ARQ/ARQ (26.4\%), and ARR/ARR (20,9\%) (9).

In Paraná state, HD as well as Suffolk animals was also imported from the U.S. in the 80s, though HD sheep were imported to a lesser degree. According the NSP classification, $43 \%$ of the HD animals tested here would be classified as type 3, 2.4\% would be classified as type 4 and $9.6 \%$ would be classified as 
type 5; thus, more than 55\% of HD animals are in the groups most susceptible to scrapie. The scrapie cases of sheep in Paraná were exclusively HD animals, showing that they are in fact very susceptible animals.

Texel

In the animals evaluated in the present study, only the genotypes ARQ/ARQ (44\%), ARR/ARQ (25\%), ARR/ ARR (19\%), and ARQ/VRQ (13\%) were found, showing a lower variability than indicated by other studies. In Dawson's classification (5), the Texel breed is among those with the greatest genetic variability. In this breed, all alleles and genotypes are normally found $(1,7)$.

Using NSP data (13), it were presented the genotypes of more than 51,000 Texel sheep, which showed the presence of all alleles. The alleles with the highest frequencies were ARH (43.7\%), followed by ARR (33.4\%), and ARQ (15.3\%). As for alleles AHQ and VRQ these showed low frequencies at $4.2 \%$ and $3.4 \%$, respectively.

In Paraná, the Texel breed is gradually growing, as its carcase is considered to be one of the best among sheep meat breeds; thus, it has attracted the attention of sheep breeders. But if a breeding program were proposed based on the NSP classification, only $18.7 \%$ (type 1) and 25\% (type 2) of these sheep would be bred, and more than $12 \%$ would be culled.

\section{Ile De France}

In the Ile de France breed, alleles ARR and ARQ were detected at frequencies $63 \%$ and $37 \%$, respectively. Compared with other meat breeds, this breed obtained the highest percentage of the ARR allele (63\%) and the highest percentage of the ARR/ARR genotype (33\%). The ARR/ARQ genotype was found in 58\% of Ile de France animals, while the ARQ/ARQ genotype was found in only $8 \%$ of these animals. It was calculated genotypic frequencies in a sample of 60 animals from 22 different flocks as $65 \%$ for ARR/ ARR, $6.7 \%$ for ARR/ARQ, 25\% for ARR/VRQ $1.7 \%$ for ARQ/VRQ and $1.7 \%$ for VRQ/VRQ (15).

In this study, the Ile de France breed had the highest number of different genetic origins (11 origins for 12 genotyped animals); as such, these samples may best represent this breed in the Paraná region. Therefore, the high percentages of more resistant genotypes within this breed (33.3\% for type 1 and $58.3 \%$ for type 2) indicate that Ile de France sheep would have a relatively large number of animals eligible for selective breeding aimed at increasing resistance to scrapie.

\section{Dorset}

Data on the genotypes of animals of this breed come from only one breeder and thus must be carefully analyzed. The most frequent genotype was ARQ/ ARQ, which was found in $56 \%$ of these animals, and ARR/ARQ, which was found in $32 \%$ of the animals. The most resistant genotype, ARR/ARR shows a $6 \%$ frequency, the same as that of one of the most susceptible genotypes, ARQ/VRQ.

The survey data from the U.S. are relatively close to the results of the present study, as they show $38.7 \%$ of Dorset sheep having the ARR/ARQ or ARQ/ARQ genotypes and 9.7\% having the ARR/ARR genotype. There was also an 8.1\% presence of ARR/VRQ animals as well as $1.6 \%$ presence of ARQ/VRQ animals (9). The origin of the Dorset sheep found in Paraná is the U.S. When the imports of this breed began, there was a ban on U.S. imports precisely because of scrapie. The result of this was that few animals formed the basic flock, thus suggesting a higher rate of inbreeding in this breed.

\section{Dorper}

The Dorper breed is of South African origin and has only recently been introduced in Brazil. In Paraná, the flock is still small, but it has been attracting the attention of breeders, who have sought out this breed as an alternative to raising pureblood animals because of the high market prices commanded by the Dorper breed.

In this breed, allele ARQ is present among $80 \%$ of sheep. The second most frequent was allele VRQ (13\%), while the ARR allele was present for only $7 \%$ of sheep. Regarding the genotypes, ARR/ARR was not found, ARQ/ARQ characterized $63 \%$ of the animals, and genotypes with less than one VRQ allele characterized 26\% of the samples. This breed had the highest percentage of animals with relatively susceptible genotypes according to the NSP classification, with $3.7 \%$ of sheep classified as type 4 and $22.2 \%$ classified as type 5 .

Data on this breed are still scarce in the literature. DeSilva et al. (9) mentioned some data on Dorper crossbred animals, but these data are presented 
together with other fur breeds, such as St. Croix and Katahdin, which makes a comparison with data from the present study impracticable.

\section{Crioula}

The Crioula breed is native to Brazil and is raised mainly in Rio Grande do Sul (Southern of Brazil) and is also present in some flocks of Paraná. Despite its low productivity, the genotyping results are interesting, as this breed presented the highest percentage of ARR/ARR animals (50\%), which is the genotype most resistant to scrapie. Usually, the most commonly-found allele in native breeds is ARQ $(8,11,14,15)$. However, because it consists of only one flock, inbreeding may have occurred among the studied animals that led to homozygosis, or selection for allele ARR, as it may be correlated with some other characteristics specific to this flock.

\section{Santa Inês}

The Santa Inês breed as well as the crossbred animals presented the highest variability found in the breeds under study; overall, these animals exhibited four alleles and six out of seven genotypes. The $43 \%$ presence of ARQ/ARQ animals, 11\% presence of ARQ/ VRQ animals, and $0 \%$ presence of ARR/ARR animals show that this breed has a high percentage of animals with genotypes very susceptible to scrapie. Because it is a Brazilian breed, there are not many data published regarding the Santa Inês. DeLima (23) presented results on 29 animals from the state of Ceará. The findings were very similar to ours: the allele ARH was not found, and six genotypes were found, including ARQ/ARQ (37.9\%), ARQ/ARR (31\%), ARR/ARR (10.3\%), AHQ/AARQ (10.3\%), AHQ/ARR $(6.9 \%)$ and VRQ/ARR (3.4\%). The largest flock of Santa Inês animals is in the northeast of Brazil. In addition, this breed has been attracting great interest in other states and regions of Brazil because of its rusticity, resistance to worms, and its absence of reproductive seasonality.

Since scrapie is present in the Suffolk and HD breeds in Paraná, the introduction of breeds such as Santa Inês, which has a profile of genotypes susceptible to scrapie, may be a matter of concern. The NSP classification shows that $50 \%$ of these animals would be classified as type 3 and more than $17 \%$ would be classified as types
4 and 5. Likewise, breeders are hoping to export this breed from Brazil, but this could be jeopardized by the breed's low genetic resistance to scrapie.

\section{Crossbreeds}

The genotyped crossbred animals came from the Pontifícia Universidade Católica do Paraná (PUCPR) flock and are results of crossing Texel, Ile de France, Hampshire Down breeds and mixed-breed animals. There is great genetic variability in these crossbreeds, with four alleles and six genotypes. The most frequently-found genotypes were ARR/ARQ (43\%), followed by ARQ/ARQ (25\%), and ARR/ARR (21\%). Genotypes ARR/VRQ ARQ/VRQ and ARQ/AHQ each appeared in less than $5 \%$ of the total sample. These are the first scrapie data on crossbred animals available in the literature on Brazilian sheep.

In a globalized world, one observes an increase in sanitary barriers, which have increasingly replaced customs and other trade barriers. As in cattle-raising, Brazil has a great potential to produce small ruminant meat for domestic consumption and for exports. Furthermore, breeds like Santa Inês and other hairy breeds have been the focus of genetic improvement efforts so that they can become a Brazilian export product. The presence of scrapie in Brazil and the profile of susceptible genotypes in the Santa Inês breed could make it difficult to export these animals. Therefore, the programs for control and surveillance of disease must be implemented with great care and responsibility to ensure the acceptance of Brazilian products overseas without any restrictions. Moreover, breeding programs should be conducted step-by-step and address the maintenance of genetic variability, adaptation, production, and disease resistance (19).

\section{References}

1. Belt PB, Muileman IH, Schreuder BE, Bos-de-Ruijter J, Gielkens AL, Smits MA. Identification of five allelic variants of the sheep PrP gene and their association with natural scrapie. J Gen Virol. 1995;76(Pt 3):509-17.

2. Hunter N, Foster JD, Goldmann W, Stear MJ, Bostock C. Natural scrapie in a closed flock of Cheviot sheep occurs only in specific PrP genotypes. Arch Virol. 1996;141(5):809-24. 
3. Hunter N, Goldmann W, Foster JD, Cairns D, Smith G. Natural scrapie and PrP genotype: case-control studies in British sheep. Vet Rec. 1997;141(6):137-40.

4. Hunter N, Moore L, Hosie BD, Dingwall WS, Greig A. Association between natural scrapie and PrP genotype in a flock of Suffolk sheep in Scotland. Vet Rec. 1997;140(3):59-63.

5. Dawson M, Hoinville LJ, Hosie BD, Hunter N. Guidance on the use of PrP genotyping as an aid to the control of clinical scrapie. Vet Rec. 1998;142(23):623-5.

6. Elsen JM, Amigues Y, Schelcher F, Ducrocq V, Andreoletti 0 , Eychennem F, et al. Genetic susceptibility and transmission factors in scrapie: detailed analysis of an epidemic in a closed flock of Romanov. Arch Virol. 1999;144(3): 431-45.

7. O'Doherty E, Healy A, Aherne M, Hanrahan JP, Weavers E, Doherty M, et al. Prion protein (PrP) gene polymorphisms associated with natural scrapie cases and their flock-mates in Ireland. Res Vet Sci. 2002;73(3):243-50.

8. Sipos W, Kraus M, Schmoll F, Achmann R, Baumgartner W. PrP genotyping of Austrian sheep breeds. J Vet Med A Physiol Pathol Clin Med. 2002;49(8):415-8.

9. DeSilva U, Guo X, Kupfer DM, Fernando SC, Pillai ATV, Najar FZ, et al. Allelic variants of ovine prion protein gene (PRNP) in Oklahoma sheep. Cytogenet Genome Res. 2003;102(1-4):89-94.

10. Billinis C, Psychas V, Leontides L, Spyrou V, Argyroudis $\mathrm{S}$, Vlemmas I, et al. Prion protein gene polymorphisms in healthy and scrapie-affected sheep in Greece. J Gen Virol. 2004;85(Pt 2):547-54.

11. Acín C, Martín-Burriel I, Goldmann W, Lyahyal J, Monzón M, Bolea R, et al. Prion protein gene polymorphisms in healthy and scrapie-affected Spanish sheep. J Gen Virol. 2004;85(Pt 7):2103-10.

12. Luhken G, Buschmann A, Groschup MH, Erhardt G. Prion protein allele $\mathrm{A}_{136} \mathrm{H}_{154} \mathrm{Q}_{171}$ is associated with high susceptibility to scrapie in purebred and crossbred German Merinoland sheep. Arch Virol. 2004;149(8): 1571-80.

13. Eglin RD, Warner R, Gubbins S, Sivam SK, Dawson M. Frequencies of PrP genotypes in 38 breeds of sheep sampled in the National Scrapie Plan for Great Britain. Vet Rec. 2005;156(14):433-7.
14. Lan Z, Wang ZL, Liu Y, Zhang X. Prion protein gene (PRNP) polymorphisms in Xinjiang local sheep breeds in China. Arch Virol. 2006;151(10):2095-101.

15. Gama LT, Carolino MI, Santos-Silva MF, Pimenta JA, Costa MS. Prion protein genetic polymorphisms and breeding strategies in Portuguese breeds of sheep. Livest Sci. 2006;99(1-2):175-84. doi.org/10.1016/j. livprodsci.2005.06.009.

16. Un C, Oztabak K, Ozdemir N, Akis I, Mengi A. Genotyping of PrP gene in native Turkish sheep breeds. Small Rumin Res. 2008;74(1-3):260-4. doi.org/10.1016/j. smallrumres.2007.06.002.

17. Groschup MH, Lacroux C, Buschmann A, Luhken G, Mathey J, Eiden M, et al. Classic scrapie in sheep with the ARR/ARR prion genotype in Germany and France. Emerging Infect Dis. 2007;13(8):1201-7.

18. Roden JA, Nieuwhof GJ, Bishop SC, Jones DA, Haresign W, Gubbins S. Breeding programmes for TSE resistance in British sheep. I. Assessing the impact on prion protein (PrP) genotype frequencies. Prev Vet Med. 2006;73(1):1-16.

19. Sotomaior CS, Sotomaior VS, Madeira HMF, ThomazSoccol V. Prion protein gene polymorphisms in sheep in the State of Paraná, Brazil. Anim Genet. 2008;39(6):659-61.

20. Hunter N. Scrapie: uncertainties, biology and molecular approaches. Biochim Biophys Acta. 2007; 1772(6): 619-28.

21. Junghans F, Teufel B, Buschmann A, Steng G, Groschup MH. Genotyping of German sheep with respect to scrapie susceptibility. Vet Rec. 1998;143(12):340-1.

22. Passos D, Ribeiro L, Rodrigues N, Hepp D, Weimer T. PrP polymorphisms in Brazilian sheep. Small Rumin Res. 2008;74(1):130-3.

23. Delima ACB, Bossers A, Souza CEA, Oliveira SMP, Oliveira DM. PrP genotypes in a pedigree flock of Santa Inês sheep. Vet Rec. 2007;160(10):336-7. 